University of Nebraska - Lincoln

DigitalCommons@University of Nebraska - Lincoln

\title{
Estimates of Duck Breeding Populations in the Nebraska Sandhills Using Double Observer Methodology
}

Mark P. Vrtiska

University of Nebraska-Lincoln, mark.vrtiska@nebraska.gov

Larkin A. Powell

University of Nebraska-Lincoln, Ipowell3@unl.edu

Follow this and additional works at: https://digitalcommons.unl.edu/natrespapers

Part of the Natural Resources and Conservation Commons

Vrtiska, Mark P. and Powell, Larkin A., "Estimates of Duck Breeding Populations in the Nebraska Sandhills Using Double Observer Methodology" (2011). Papers in Natural Resources. 348.

https://digitalcommons.unl.edu/natrespapers/348

This Article is brought to you for free and open access by the Natural Resources, School of at DigitalCommons@University of Nebraska - Lincoln. It has been accepted for inclusion in Papers in Natural Resources by an authorized administrator of DigitalCommons@University of Nebraska - Lincoln. 


\title{
Estimates of Duck Breeding Populations in the Nebraska Sandhills Using Double Observer Methodology
}

\author{
Mark P. VRTISKA ${ }^{1, *}$ AND LARKIN A. POWELL ${ }^{2}$ \\ ${ }^{1}$ Nebraska Game and Parks Commission, 2200 N. 33rd Street, Lincoln, NE, 68503, USA \\ ${ }^{2}$ School of Natural Resource Sciences, 419 Hardin Hall, University of Nebraska, \\ Lincoln, NE, 68586-0974, USA \\ *Corresponding author; E-mail: mark.vrtiska@nebraska.gov
}

\begin{abstract}
The Nebraska Sandhills are an important area for breeding ducks in the Great Plains, but reliable estimates of breeding populations are unavailable. Double-observer methodology was used to estimate abundance of breeding duck populations in the Nebraska Sandhills. Aerial transect surveys were conducted using methodology similar to the cooperative Waterfowl Breeding Population and Habitat Survey conducted by the U.S. Fish and Wildlife Service and Canadian Wildlife Service. Observations by two front-seat observers and one rear-seat observer were used to account for incomplete detectability. Transect-specific population size and detection probabilities were estimated using program SURVIV; estimates were species-specific by type of social grouping. Regional population sizes were obtained by extrapolating transects' estimates to the Sandhills. Detection probabilities were high $(>0.75)$ for all species, but highest for Northern Shoveler (Anas clypeata) and Gadwall (A. strepera). Detection probabilities generally followed increases or decreases with duck densities. Uncorrected population estimates, on average, were $<7 \%$ the population estimates obtained by correcting for detectability. Double-observer methodology should be considered for adjusting duck counts that cannot be corrected using additional aerial or ground surveys, particularly where water and ducks are well dispersed. Received 19 April 2010, accepted 24 August 2010.

Key words.-Aerial survey, Anas, detection probabilities, double observer, Nebraska, population estimation, Sandhills.
\end{abstract}

Waterbirds 34(1): 96-101, 2011

Estimates of breeding populations are fundamental to waterfowl management and habitat conservation (Cowardin and Blohm 1992). For most waterfowl populations, use of aerial surveys is necessary given the large size and inaccessibility of areas used by waterfowl (Cowardin and Blohm 1992). However, visibility bias resulting from animals being missed by observers during aerial surveys is well known (Caughley 1974, 1977). The annual Waterfowl Breeding Population and Habitat Survey (WBPHS) uses concurrent ground surveys in Prairie-Parkland areas to obtain visibility correction factors (VCFs) to accurately estimate waterfowl populations (U.S. Fish and Wildlife Service and Canadian Wildlife Service 1987; Smith 1995; Koneff et al. 2008). Due to the forested habitats and lack of roads, helicopters have been used to obtain VCFs in the boreal and tundra portions of the WBPHS (U.S. Fish and Wildlife Service 2009; Koneff et al. 2008).

An annual aerial survey was conducted to estimate the breeding population of ducks in the Nebraska Sandhills from 1966-2002, but no attempt was made to determine visibility bias or detection probabilities of the survey and provide more reliable population estimates. Unlike the Prairie-Parkland areas of the WBPHS, there is not an established network of roads across the entire portion of the Sandhills to conduct concurrent ground counts. Additionally, techniques such as follow-up helicopter surveys that are used in other areas of the WBPHS are cost prohibitive. Koneff et al. (2008) evaluated doubleobserver methodology to estimate detection rates during aerial waterfowl population surveys. A single observation platform (e.g. aircraft) can be an efficient and inexpensive (Caughley 1974; Cook and Jacobson 1979; Caughley and Grice 1982) method to obtain population estimates, especially when waterfowl densities are low (requiring longer transects to achieve critical sample sizes, and thus resource intensive for repeated surveys) and ground access limited (prohibiting ground-based observers that could be used to obtain VCFs; Koneff et al. 2008). While double-observer methodology has been used 
for ungulates (e.g. Potwin et al. 2004) and in conjunction with avian point counts (Nichols et al. 2000), there have been few reported evaluations for waterfowl surveys (e.g. Johnson et al. 1989; Koneff et al. 2008). Thus, the objectives of our study were to estimate population size of breeding ducks in the Sandhills and to evaluate the effectiveness of continued use of aerial double-observer methodology for estimating breeding ducks in the Sandhills.

\section{METHODS}

\section{Study Area}

The Sandhills and Sandhills borders region of northcentral Nebraska (Fig. 1) is approximately 19,300 $\mathrm{km}^{2}$ and is the largest stabilized sand dune area in North America (Novacek 1989). The region is comprised of large tracts of mixed grass prairie interspersed with small to large wetlands, meadows and lakes (LaGrange 2005 ). Predominant land use in this region is cattle production with approximately $5 \%$ of the land area devoted to row crop production (Novacek 1989; Miller 1990). Mallard (Anas platyrhynchos), Gadwall (A. strepera), Bluewinged Teal (A. discors), Northern Shoveler (A. clypeata) and Northern Pintail (A. acuta) are the primary species of ducks nesting in the Sandhills (Sharpe et al. 2001).

\section{Survey and Population Estimation}

Our aerial survey methodology and protocols were analogous to that of the WBPHS (U.S. Fish and Wildlife Service and Canadian Wildlife Service 1987). Transects were flown using a Cessna 185 (Cessna Aircraft Company, Wichita, KS) at 30-40 $\mathrm{m}$ above ground level at a speed of approximately $140-170 \mathrm{~km} / \mathrm{h}$. On the WBPHS, single males (lone hens are not counted), pairs (male and female), flocked drakes and flocked ducks are enumerated by the pilot-observer and an observer out to a distance of $200 \mathrm{~m}$ on each side of the aircraft. All observers in our study had previous experience (5-20 years) with the WBPHS methodology and identification of ducks from the air.

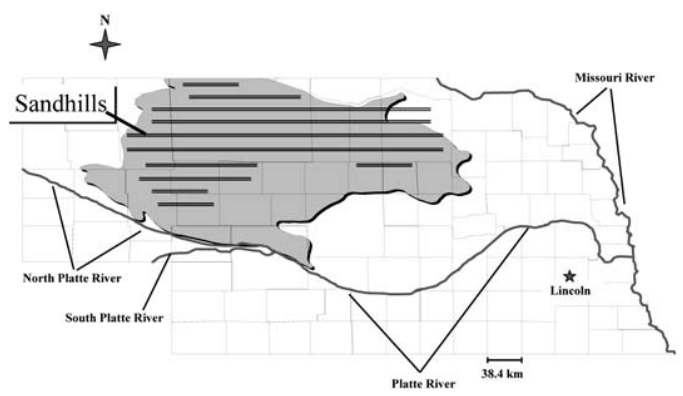

Figure 1. Location (shaded portion) of the Nebraska Sandhills and Sandhills borders region. Lines represent approximate location and length of transects flown for aerial survey of breeding ducks.
We modified the WBPHS methods to incorporate the double-observer methods of Koneff et al. (2008). As for the WBPHS, we used two observers in the front seats of the aircraft; each counted birds only on their side of the plane. We added a third observer in the rear seat of the aircraft, who operated as the secondary observer during our double-observer study (Koneff et al. 2008). All observers independently enumerated ducks (Koneff et al. 2008). Weight restrictions limited use to only one person in the rear seat; thus, we had to alternate the side of the aircraft in which the secondary observer sat. To account for changes in conditions during the survey, we randomly selected the starting side that the third observer monitored; we alternated at the end of each transect.

Physical barriers are often used to ensure independence among observers (Caughley 1974; Koneff et al. 2008). We could not use a physical barrier (e.g. curtain) between the primary and secondary observer because: 1 ) the secondary observer would be handicapped in observing upcoming wetlands; and 2) modifications to the aircraft used for the survey were not possible. We are comfortable with the independence of our observers' data; given the aircraft's speed, relative to altitude, observers had to maintain focus on the ground, with no opportunity to glance at the other observer. Direct observation of movements between observers was restricted due to seating arrangement of observers or the physical barrier of the front observer's seat. Additionally, survey protocol provided to observers enforced the need to avoid revealing they had observed ducks prior to reconciliation of ducks and counts between observers.

All observers used cassette recorders to document counts of ducks. Immediately after flying over water bodies or observing ducks and prior to the next observation, the front and rear-seat observers reconciled species identification, social grouping and counts to ensure correct enumerations of ducks. The reconciliation process was conducted verbally by observers alternatively inquiring whether the other observer had any observations of ducks and then recorded by the backseat observer. On large lakes where numerous waterfowl were concentrated and counts could not be reconciled before the next observation, attempts were made by each observer to make independent counts of waterfowl. Observations of ducks were then reconciled and based on sequence of observation, social grouping or other factors, observations were categorized accordingly (see below). Only those observations that were reconciled between both observers were included for estimates of delectability. After reconciling, our data consisted of ducks or duck groups that were: 1) observed by both observers; 2) observed by the front-seat observer but not the rear-seat observer; or 3) observed by the rear-seat observer but not the front-seat observer (Koneff et al. 2008). Encounter histories similar to Koneff et al. (2008) were developed for each observation.

We used a double-observer approach (Nichols et al. 2000) but applied the independent observer models of Moore et al. (2004) and Fletcher and Hutto (2006) to investigate species, social grouping, and transect as potential sources of variation in detection probability. Initially, we constructed two-occasion capture histories for each species, and used program DOBSERV (J. Hines, pers. comm.) to create input code for program SURVIV (White 1983). We evaluated competing models with observer-specific, transectspecific, and observation type-specific (single, pair, 
flock) detection probabilities. When data were sparse $(<10$ observations/transect), we grouped data across transects. We used Akaike's Information Criterion (AIC) (Burnham and Anderson 1998) in program SURVIV to compare and select the best model for each species, and we compared detection probabilities among species using confidence intervals.

We used two methods to calculate breeding duck populations in the Sandhills. We followed methodology used in the WBPHS (U.S. Fish and Wildlife Service and Canadian Wildlife Service 1987) to calculate breeding pairs: a single male, flocked males in groups $<5$, and observed pairs are scored as a breeding pair. The design of our study allowed us to use, per WBPHS methods, the two front-seat observers' raw counts as the data for this calculation. We calculated the area surveyed $\left(A_{t}\right)$ as the product of the length of our aerial survey transects and the survey sampling width of 400 meters. First, we used an expansion factor, $c$, to extrapolate the raw count $\left(n_{c}\right)$ in the area surveyed $\left(A_{t}\right)$ to the population of breeding ducks $\left(\hat{N}^{n}\right)$ in the area of the Nebraska Sandhills, $A_{S}$, (approximately $35,360 \mathrm{~km}^{2}$ ), where $c=\frac{A_{t}}{A_{s}}$ :

$$
\hat{N}^{\prime}=\frac{n_{c}}{c},
$$

where $\hat{N}^{\prime}$ was not corrected for detectability. WBPHS methodology does not provide for the calculation of $95 \%$ confidence intervals for the estimate of $\hat{N}^{\prime}$. Second, for comparison with VCF-corrected population estimates typically used by other state and federal agencies, we used our detection rate estimates $(\hat{p})$ to calculate the Sandhills breeding duck population. Cor rected population size $(\hat{N})$ was extrapolated from our sample to the Sandhills in the same manner as $\hat{N}$, except we corrected our raw counts $\left(n_{c}\right)$ on each transect with the appropriate detection rate estimate $(\hat{p})$ from the best model:

$$
\hat{N}=\frac{n_{c}}{\hat{p} \cdot c}
$$

To derive a confidence interval for $\hat{N}$, we used the delta method, following Powell (2007) to approximate the variance of $\hat{N}$ as a function of the variance of $\hat{p}$ :

$$
\operatorname{vâr}(\hat{N})=\operatorname{vâr}(\hat{p}) \cdot\left(\frac{n_{c}^{2}}{c^{2} \hat{p}^{4}}\right)
$$

\section{RESULTS}

Over the three years of the study, we counted more Mallards than other breeding duck species in the Sandhills; Blue-winged Teal, Gadwall, Northern Shoveler and Northern Pintail were the other top species (Table 1). Nine other species of ducks were observed during the survey (Table 1), but our uncorrected estimate of breeding population for other ducks was $<2,000$ for each species. The estimates, not corrected for detectability, suggested that 70,000-118,000 ducks used the Sandhills region during 2003-2005.

Detection probabilities of breeding ducks in our study ranged from $88-95 \%$ (Table 2) and detection rates did not vary by observer. Also, we did not find evidence of differences in detectability among transects or social grouping. We selected the constant detectability model $[\mathrm{P}(.,)$.$] in each of the spe-$ cies-pooled analyses, as well as the speciesspecific comparisons except for Northern Shovelers in 2005. The $\mathrm{P}(.,$.$) model had ei-$ ther the lowest $\mathrm{AIC}_{\mathrm{c}}$ score or was $<2.0$ of the lowest AIC score with fewer parameters $(K)$. The social grouping-specific (singles, pairs, groups) detection model $[\mathrm{P}(\mathrm{S},)$.$] had the$ lowest $\mathrm{AIC}_{\mathrm{c}}$ score $\left(\mathrm{AIC}_{\mathrm{c}}=8.02\right)$ for Northern Shovelers in $2005\left(\mathrm{P}(.,.) \mathrm{AIC}_{\mathrm{c}}=12.27\right)$. Detection probabilities were higher in years with fewer ducks and generally highest for Northern Shoveler and Gadwall (Table 3). Our uncorrected population estimates ( $\mathrm{Ta}$ ble 1) averaged $93 \%$ of the estimates corrected for detectability (Tables 2 and 3).

Table 1. Uncorrected breeding population estimates from aerial transect counts for the five most abundant duck species and total ducks in the Nebraska Sandhills, 2003-2005. Other species encountered, with estimates of $<2000$ individuals were: American wigeon (A. americana), American green-winged teal (A. crecca), wood duck (Aix sponsa), redhead (Aythya americana), canvasback (A. valisineria), lesser scaup (A. affinis), ring-necked duck (A. collaris), bufflehead (Bucephala albeola) and ruddy duck (Oxyura jamaicensis).

\begin{tabular}{lcccccc}
\hline \hline Year & Mallard & Blue-winged Teal & Gadwall & Northern Shoveler & Northern Pintail & Total Ducks \\
\hline 2003 & 32,925 & 23,822 & 19,463 & 7,631 & 6,400 & 96,719 \\
2004 & 23,235 & 13,748 & 15,105 & 7,825 & 2,715 & 69,896 \\
2005 & 29,322 & 30,670 & 17,981 & 21,575 & 4,243 & 117,114 \\
Mean & 28,494 & 22,747 & 17,516 & 16,288 & 4,453 & 94,576 \\
\hline
\end{tabular}


Table 2. Number of observations of breeding ducks counted $\left(x_{1,3}\right)$ during aerial transect surveys in the Nebraska Sandhills during 2003-2005 by primary and secondary observer and estimated detection probability, $p$. (SE) from a constant detection model $[\mathrm{P}(.,)$.$] in program DOBSERV. Adjusted annual population estimates (N)$, 95\% confidence intervals (CI), for ducks in the Sandhills region were calculated using observations of breeding ducks seen by the front-seat observers, year-specific detection rate estimates $(p$.$) , and an adjustment for total area of the San-$ dhills region.

\begin{tabular}{lcccc}
\hline \hline & \multicolumn{4}{c}{ Detection probability } \\
\cline { 2 - 5 } Year & $x_{1,3}$ & $p .(\mathrm{SE})$ & $N$ & $95 \%$ CI \\
\hline 2003 & 444 & $0.902(0.034)$ & 107,880 & $100,202-115,558$ \\
2004 & 368 & $0.954(0.013)$ & 77,191 & $75,120-79,253$ \\
2005 & 478 & $0.886(0.037)$ & 123,554 & $113,441-133,667$ \\
\hline
\end{tabular}

Table 3. Species-specific detection probability, $p$. (SE), for breeding ducks observed during double-observer, aerial transect surveys in the Nebraska Sandhills during 2003-2005. Estimate is from a constant detection model [P(.,.)] in program DOBSERV. Adjusted annual population estimates, $N$ and $95 \%$ confidence interval, for each species in the Sandhills region were calculated using the number of breeding ducks seen by the front-seat observers, speciesspecific detection rate $(p$.$) and an adjustment for total area of the Sandhills region.$

\begin{tabular}{|c|c|c|c|c|}
\hline Species & Year & $p .(\mathrm{SE})$ & $N$ & $95 \% \mathrm{CI}$ \\
\hline Mallard & $\begin{array}{l}2003 \\
2004 \\
2005\end{array}$ & $\begin{array}{l}0.813(0.079) \\
0.934(0.033) \\
0.859(0.085)\end{array}$ & $\begin{array}{l}37,308 \\
24,689 \\
31,878\end{array}$ & $\begin{array}{l}30,277-44,339 \\
22,979-26,399 \\
25,524-38,232\end{array}$ \\
\hline Blue-winged Teal & $\begin{array}{l}2003 \\
2004 \\
2005\end{array}$ & $\begin{array}{ll}0.823 & (0.078) \\
0.911 & (0.054) \\
0.925 & (0.035)\end{array}$ & $\begin{array}{l}27,400 \\
14,686 \\
31,150\end{array}$ & $\begin{array}{l}22,687-32,113 \\
12,980-16,392 \\
28,773-33,527\end{array}$ \\
\hline Gadwall & $\begin{array}{l}2003 \\
2004 \\
2005\end{array}$ & $\begin{array}{l}0.883(0.072) \\
0.984(0.014) \\
0.995(0.006)\end{array}$ & $\begin{array}{l}20,674 \\
15,244 \\
17,598\end{array}$ & $\begin{array}{l}17,553-23,795 \\
14,819-15,669 \\
17,385-17,811\end{array}$ \\
\hline Northern Shoveler & $\begin{array}{l}2003 \\
2004 \\
2005\end{array}$ & $\begin{array}{l}0.924(0.061) \\
0.967(0.036) \\
0.880(0.093)\end{array}$ & $\begin{array}{r}8,152 \\
8,004 \\
22,123\end{array}$ & $\begin{array}{l}7,116-9,188 \\
7,420-8,588 \\
17,190-27,056\end{array}$ \\
\hline Northern Pintail & $\begin{array}{l}2003 \\
2004 \\
2005\end{array}$ & $\begin{array}{l}0.816(0.179) \\
0.910(0.119) \\
0.889(0.128)\end{array}$ & $\begin{array}{l}7,566 \\
2,956 \\
4,580\end{array}$ & $\begin{array}{l}4,507-10,625 \\
2,198-3,714 \\
3,248-5,912\end{array}$ \\
\hline
\end{tabular}

\section{DISCUSSION}

Although the Sandhills of Nebraska have been considered the most important area for breeding ducks south of the Prairie Pothole Region (Bellrose 1980), our data represent the first estimates of duck breeding populations in the Nebraska Sandhills. However, population estimates obtained in our study were lower compared to recent years when habitat conditions were more favorable (Vrtiska 2005). For example, in 1999, uncorrected breeding population estimates of all ducks were approximately 250,000 ducks, including 81,000 mallards (Vrtiska 2005). Thus, if our detection probabilities were applied to this estimate, the Sandhills may have
$>275,000$ breeding ducks under favorable conditions.

Our population estimates for breeding ducks in the Sandhills can be used for baseline information for conservation planning objectives. Furthermore, these data and methodology used provide information that could be used to evaluate potential impacts of future land and water use changes in this region. Emerging threats to the Sandhills landscape include agricultural and wind development, water-use policies and climate change. All of these threats may occur at large scales that would require region-wide evaluation.

Our estimated detection rates of $88-95 \%$ were higher and less variable than the rates 
of $43-84 \%$ those reported by Koneff et al. (2008). The disparity between the habitat of the two study areas (i.e. wetlands interspersed within forested habitats vs. wetlands in mixed-grass prairie) that allowed increased visibility of wetlands and ducks in our study probably explains the greater detection rates we observed. Furthermore, densities of breeding ducks between the two areas also favored greater detection rates in our study. Our observers also had previous experience ( $\geq 5$ years) in flying these survey transects or participated in the WBHPS survey; experienced observers can be expected to anticipate potential observation opportunities for ducks and possess the skills to efficiently scan areas for ducks, which may have contributed to our high detection rates. Thus, our situation may not apply to different habitats or situations; the double observer method provides evidence of detection levels, which may change with changes in water levels, duck density, or observers. We note that the double observer method accounts for incomplete detection, which is conditioned on the availability of the animal to be counted. Ducks hidden, to both observers, in tall vegetation would be an example of 'unavailable' birds. Nichols et al. (2000) and Koneff et al. (2008) discuss approaches that have potential to account for both forms of bias.

There are many factors that can affect observation of animals (Cook and Jacobson 1979), but annual differences in survey (e.g. density of ducks, cloudy and calm vs. sunny and windy) conditions were likely the primary source of variation of detection probabilities among years, given that other variables which could influence observations or detectability, such as different observers or type of aircraft, were the same in all years of our study. While differences in bird size, color and behavior may make some species more readily detectable than others, we found detection rates among species rather homogeneous. Blue-winged Teal, one of the smaller duck species, had similar detection rates as Mallard and Northern Pintail. Also, species composition did not change much between years in our study. Future studies should in- vestigate possible differences in detection rates among species and social groupings of ducks.

Because observations of wetland or ducks sometimes came in rapid succession and short recollection time of what was observed, immediate reconciliation of identity and counts of ducks after observation was critical in obtaining accurate estimates. We did have difficulty in reconciling counts when encountering large water bodies where numerous birds and flocks were observed and observers could not reconcile counts accurately. We did attempt to identify large water bodies and reconcile independent possible duplicate or separate observations of ducks. Although Koneff et al. (2008) used GPS technology that automatically coupled specific locations with observations, they found that immediate reconciliation was still important for accurate counts. Using GPS technology may have improved our reconciliation over large water bodies more feasible and accurate in our study.

Double-observer methodology allowed us to adjust population estimates from aerial waterfowl surveys without the cost of additional aircraft and crews in a region where other methods of obtaining VCFs were limited. As Koneff et al. (2008) recommended, we believe this technique has applicability in other regions where ground counts or the cost of follow-up aerial surveys is prohibitive and which have duck densities similar to our study. We do not know how detection probabilities would have been affected by higher densities and future investigations should examine the usefulness of this method with different habitats and duck densities. Additionally, comparisons of detection probabilities with double observers and VCFs obtained via ground counts would provide more insight into the accuracy of double-observer methodology.

\section{ACKNOWLEDGMENTS}

We thank J. D. Nichols and J. E. Hines, USGS, for their encouragement to use double-observer methodology and assistance with data analysis and comments on earlier versions of this manuscript. D. Benning, N. Lyman, R. Walters, T. Krolikowski and F. Mueller assisted 
with data collection. M. Koneff and two anonymous reviewers provided comments on the manuscript. The research was supported by Hatch Act funds through the University of Nebraska Agricultural Research Division, Lincoln, Nebraska. Funding was through the Nebraska Game and Parks Commission and the Federal Aid in Wildlife Restoration W-15-R.

\section{LITERATURE CITED}

Bellrose, F. C. 1980. Ducks, geese and swans of North America. Stackpole Books, Harrisburg, Pennsylvania.

Burnham, K. P. and D. R. Anderson. 1998. Model selection and inference: A practical information-theoretic approach. Springer-Verlag, New York, New York.

Caughley, G. 1974. Bias in aerial survey. Journal of Wildlife Management 38: 921-933.

Caughley, G. 1977. Analysis of vertebrate populations. John Wiley and Sons, Inc., New York, New York.

Caughley, G. and D. Grice. 1982. A correction factor for counting emus from the air, and its application to counts in western Australia. Australian Wildlife Research 9: 253-259.

Cook, R. D. and J. O. Jacobson. 1979. A design for estimating visibility bias in aerial surveys. Biometrics 35 : 735-742.

Cowardin, L. M. and R. J. Blohm. 1992. Breeding population inventories and measures of recruitment. Pages 423-445 in Ecology and management of breeding waterfowl (B. D. J. Batt, A. D. Afton, M. G. Anderson, C. D. Ankney, D. H. Johnson, J. A. Kadlec and G. R. Krapu, Eds.), University of Minnesota Press, Minneapolis, Minnesota.

Fletcher, R. J., Jr. and R. L. Hutto. 2006. Estimating detection probabilities of river birds using double surveys. Auk 123: 695-707.

Johnson, F. A., K. H. Pollack and F. Montalbano. 1989. Visibility bias in aerial surveys of Mottle Ducks. Wildlife Society Bulletin 17: 222-227.

Koneff, M. D., J. A. Royle, M. C. Otto, J. S. Wortham and J. K. Bidwell. 2008. A double-observer method to estimate detection rate during aerial waterfowl surveys. Journal of Wildlife Management 72: 1641-1649.

LaGrange, T. 2005. Guide to Nebraska's wetlands and their conservation needs. Nebraska Game and Parks Commission, Lincoln, Nebraska.
Miller, S. M. 1990. Land development and use. Pages 207226 in An Atlas of the Sandhills (A. Bleed and C. Flowerday, Eds.). Conservation and Survey Division, University of Nebraska-Lincoln, Lincoln, Nebraska.

Moore, J. E., D. M. Scheiman and R. K. Swihart. 2004. Field comparison of removal and modified doubleobserver modeling for estimating detectability and abundance of birds. Auk 121: 865-876.

Nichols, J. D., J. E. Hines, J. R. Sauer, F. W. Fallon, J. E. Fallon and P. J. Heglund. 2000. A double-observer approach for estimating detection probability and abundance from point counts. Auk 117: 393-408.

Novacek, J. M. 1989. The water and wetland resources of the Nebraska Sandhills. Pages 340-384 in Northern Prairie Wetlands (A. van der Valk, Ed.). Iowa State University Press, Ames, Iowa.

Potwin, F., L. Breton and L. Rivest. 2004. Aerial surveys for white-tailed deer with the double-count technique in Quebec: Two 5-year plans completed. Wildlife Society Bulletin 32: 1099-1107.

Powell, L. A. 2007. Approximating variance of demographic parameters using the delta method: A reference for avian biologists. Condor 109: 950-955.

Sharpe, R. S., W. R. Silcock and J. G. Jorgensen. 2001. Birds of Nebraska: Their distribution and temporal occurrence. University of Nebraska Press, Lincoln, Nebraska.

Smith, G. W. 1995. A critical review of the aerial and ground surveys of breeding waterfowl in North America. U.S. Department of Interior, National Biological Service, Biological Science Report 5.

U.S. Fish and Wildlife Service and Canadian Wildlife Service. 1987. Standard operation procedures (SOP) for aerial waterfowl breeding ground population and habitat surveys in North America. U.S. Fish and Wildlife Service, Washington, D.C.

U.S. Fish and Wildlife Service. 2009. Waterfowl population status, 2009. U.S. Department of the Interior, Washington, D.C.

Vrtiska, M. P. 2005. Unit report: Nebraska Sandhills Breeding Duck Population Estimates-2005. Nebraska Game and Parks Commission, Lincoln, Nebraska.

White, G. C. 1983. Numerical estimation of survival rates from band-recovery and biotelemetry data. Journal of Wildlife Management 47: 716-728. 